\title{
NITROGEN SUPPLY TO CORN FROM SUNN HEMP AND VELVET BEAN GREEN MANURES
}

\author{
Edmilson José Ambrosano ${ }^{1 *}$; Paulo Cesar Ocheuze Trivelin²; Heitor Cantarella ${ }^{3}$; Gláucia \\ Maria Bovi Ambrosano ${ }^{4}$; Eliana Aparecida Schammass ${ }^{5}$; Takashi Muraoka ${ }^{2}$; Nivaldo Guirado ${ }^{1}$; \\ Fabrício Rossi ${ }^{1}$ \\ ${ }_{2}^{1}$ APTA - Pólo Regional Centro Sul, C.P. 28 - 13400-970 - Piracicaba, SP - Brasil. \\ ${ }^{2}$ USP/CENA - Lab. de Isótopos Estáveis e Nutrição de Plantas, C.P. 96 - 13400-970 - Piracicaba, SP - Brasil. \\ ${ }^{3}$ APTA/IAC - Centro de Solos e Recursos Agroambientais, C.P. 28 - 13001-970 - Campinas, SP - Brasil. \\ ${ }_{5}^{4}$ UNICAMP/FOP - Depto. de Odontologia Social, Bioestatística, C.P. 52 - 13414-903-Piracicaba, SP - Brasil. \\ ${ }^{5}$ APTA/IZ, Bioestatistica, R. Heitor Penteado, 56 - 13460-000 - Nova Odessa, SP - Brasil. \\ *Corresponding author <ambrosano@apta.sp.gov.br>
}

\begin{abstract}
Due to their nitrogen fixation potential, legumes represent an alternative for supplying nutrients, substituting or complementing mineral fertilization in cropping systems involving green manuring. The objective of this study was to evaluate the $\mathrm{N}$ balance in a soil-plant system involving green manures [sunn hemp (Crotalaria juncea L.) and velvet bean (Mucuna aterrima Piper \& Tracy)], both labeled with ${ }^{15} \mathrm{~N}$. They were incorporated into two soils of contrasting textural classes: a clayey Eutrudox and a sandy-clayey Paleudalf, both cultivated with corn. The research was carried out in a greenhouse, using pots containing $6 \mathrm{~kg}$ of air dried soil, to which the equivalent to $13 \mathrm{Mg} \mathrm{ha}^{-1}$ dry matter of above-ground mass plus 2.7 or $2.2 \mathrm{Mg} \mathrm{ha}^{-1}$ of velvet bean and sunn hemp roots were incorporated, respectively, with ${ }^{15} \mathrm{~N}$ labeling of either shoots or roots. One hundred days after emergence of the corn, the velvet bean residues provided higher accumulation of $\mathrm{N}$ in the soil, higher absorption by corn plants and accumulation in the shoot. The green manure decomposition was more intense in the medium-textured Paleudalf. The highest nitrogen losses were also observed in this soil.

Key words: Crotalaria juncea L., Mucuna aterrima Piper \& Tracy, mineralization, ${ }^{15} \mathrm{~N}$, isotope dilution

\section{FORNECIMENTO DE NITROGÊNIO AO MILHO PELOS ADUBOS VERDES CROTALÁRIA JÚNCEA E MUCUNA PRETA}

\begin{abstract}
RESUMO: Em função de seu potencial de fixação de nitrogênio, as leguminosas representam uma alternativa ao suprimento, substituição ou complementação da adubação mineral em sistemas de cultivos envolvendo adubação verde. O objetivo deste estudo foi avaliar o balanço do $\mathrm{N}$ no sistema solo planta com adubos verdes crotalária júncea (Crotalaria juncea L.) e mucuna-preta (Mucuna aterrima Piper \& Tracy), marcadas com ${ }^{15} \mathrm{~N}$, incorporadas em dois solos de diferentes classes texturais: Latossolo Vermelho eutroférrico textura argilosa, A moderado (LVef) e Argissolo Vermelho-Amarelo distrófico textura arenosa/média, A moderado (PVAd), e cultivados com milho. O trabalho foi desenvolvido em casa-de-vegetação, em vasos contendo $6 \mathrm{~kg}$ de terra aos quais foi incorporado o equivalente a $13 \mathrm{Mg} \mathrm{ha}^{-1}$ de massa seca da parte aérea e 2,7 ou 2,2 $\mathrm{Mg} \mathrm{ha}^{-1}$ de raízes de mucuna-preta e de crotalária júncea, respectivamente. A marcação com ${ }^{15} \mathrm{~N}$ foi efetuada ou nas raízes ou na parte aérea. Cem dias após emergência do milho, a incorporação de mucuna-preta aos solos proporcionou maior acúmulo de nitrogênio no solo, maior absorção do elemento pelas plantas de milho e sua acumulação na parte aérea. A decomposição da parte aérea e raízes dos adubos verdes foi mais intensa no solo de textura média (PVAd). Neste solo, também, foram observadas as maiores perdas de nitrogênio. Palavras-chave: Crotalaria juncea L., Mucuna aterrima Piper \& Tracy, mineralização, ${ }^{15} \mathrm{~N}$, diluição isotópica
\end{abstract}

\section{INTRODUCTION}

The incorporation of plant materials to soils, with the objective of maintaining or improving fertility for the subsequent crop is known as green manuring. Because of its nitrogen fixation potential, legumes represent an alternative for supplying nutrients, substituting or complementing mineral fertilization in cropping systems involving green manuring. According to Montojos \& Gargantini (1963), this practice, known for centuries, causes changes in soil physical, chemical and biological characteristics, bringing benefits to 
the subsequent crop (Gallo et al., 1983; Gallo et al., 1986; Pereira et al., 1988; Kanthack et al., 1991 and Tanaka et al., 1992) both in small-scale cropping systems and in larger commercial areas such as those grown with sugarcane (Mascarenhas et al., 1994; Ambrosano et al., 2005).

Residue incorporation studies of legumes using ${ }^{15} \mathrm{~N}$ label indicate that 10 to $34 \%$ of the legume $\mathrm{N}$ can be recovered in the subsequent rye or wheat crop (Ladd et al., 1981b, 1983; Azam et al., 1986; Muller \& Sundman, 1988; Ta \& Faris, 1990), 42\% in rice (Silva, 1991), 24\% recovery from Velvet bean by corn crop (Scivittaro et al., 2003), around $15 \%$ of $\mathrm{N}$ recovery from sunn hemp in corn plants in no-till system (Silva, 2005) and 5\% of $\mathrm{N}$ recovery from sunn hemp by sugarcane (Ambrosano et al., 2005).

Ladd et al. (1981b) incorporated Medicago littoralis into two soil types and observed that the mineralization rate of $\mathrm{N}$ of the legume residue was more intense in the less fertile soil. In this soil the $\mathrm{N}$ mineralization rates were around $10 \%$, while in the most fertile soil around $5 \%$, in samples collected after wheat seeding and after the flowering, respectively. The authors suggested that legume residue decomposition provided long-term supply of $\mathrm{N}$ for the subsequent crops, by not supplying the nutrient as an immediate source.

The objective of this study was to evaluate the utilization of $\mathrm{N}$ by the corn plant, from legumes parts (shoots and roots) incorporated into the soil, and also understand the recovery of the soil nitrogen process in the soil-plant system.

\section{MATERIAL AND METHODS}

A sandy-clayey Paleudalf (PVAd) and a clayey Eutrudox (LVef), collected from the $0-20 \mathrm{~cm}$ layer were used. The soil chemical characteristics, before and after the incorporation of nutrients were evaluated according to Raij et al. (2001) and are shown in Table 1. The study was carried out in pots containing $6 \mathrm{~kg}$ of air dried soil, corresponding to 5.3 and $4.7 \mathrm{~kg}$ for the of oven-dried soil $\left(110^{\circ} \mathrm{C}\right)$ for the Paleudalf and the Eutrudox, respectively. All calculations were based on oven-dried soil.

Eight days before incubation the soil of each pot was fertilized with $1 \mathrm{~g}$ per pot of $\mathrm{P}$ (triple superphosphate); $700 \mathrm{mg}$ per pot of $\mathrm{K}$ (potassium chloride); $250 \mathrm{mg}$ per pot of $\mathrm{Mg}$ (magnesium oxide); $20 \mathrm{mg}$ per pot of $\mathrm{Zn}$ (zinc sulphate); $20 \mathrm{mg}$ per pot of Mn (manganese sulphate); $6 \mathrm{mg}$ per pot of $\mathrm{Cu}$ (copper sulphate); $2 \mathrm{mg}$ per pot of $\mathrm{B}$ (boric acid). To raise the base saturation to $70 \%$ only the PVAd received $5.4 \mathrm{~g}$ per pot of a mixture 3:1 of $\mathrm{CaCO}_{3}$ and $\mathrm{MgCO}_{3}$. A basal fertilization was made in all treatments to ensure full corn development following the suggestion of Bull \& Cantarella (1993). Eight days after soil fertilization and incorporation new samples were collected and analyzed (Table 1).

\section{Green manures labeling with ${ }^{15} \mathrm{~N}$}

In the first experimental phase velvet bean and sunn hemp were sown and labeled with ${ }^{15} \mathrm{~N}$, as described by Ambrosano et al. (1997). Nitrogen (1.2 g) was applied as ammonium sulphate with $11.37{ }^{15} \mathrm{~N}$ atoms $\%$ excess, in three split-applications. The dried labeled material contained 3.177 e $4.337 \%{ }^{15} \mathrm{~N}$ atoms, for velvet bean and sunn hemp respectively. The green manures were cut 94 days after emergence, when plants still had not reached flowering stage.

\section{Green manures incorporated into the soils}

The incubation was performed with $39 \mathrm{~g}$ per pot of dry matter of the above-ground parts of sunn hemp and velvet bean, equivalent to $13 \mathrm{Mg} \mathrm{ha}^{-1}$ of dry matter. Roots were also added: 6.6 and $8.6 \mathrm{~g}$ per pot of root dry matter, corresponding to 2.8 and $2.2 \mathrm{Mg} \mathrm{ha}^{-1}$, respectively, of the sunn hemp and velvet bean, following the proportions of above- and below-ground parts obtained in the pots, $16.7 \%$ and $21.3 \%$ respectively of sunn hemp and velvet bean, as described in Ambrosano et al. (1997). Soils were incubated for 36 days, before corn sowing, and monitored for nitrogen immobilization, which was not observed (Ambrosano et al., 2003).

The incubation was carried out in a greenhouse, whose climatological data is shown in Figure

Table 1 - Chemical characterization of the soils used in the experiment.

\begin{tabular}{|c|c|c|c|c|c|c|c|c|c|}
\hline \multirow{2}{*}{ Soil } & \multicolumn{9}{|c|}{ Original soil before liming and chemical fertilization } \\
\hline & $\mathrm{pH}\left(\mathrm{CaCl}_{2}\right)$ & O. M. & $\mathrm{P}$ & $\mathrm{K}$ & $\mathrm{Ca}$ & $\mathrm{Mg}$ & $\mathrm{H}+\mathrm{Al}$ & $\mathrm{T}$ & $\mathrm{V}$ \\
\hline & $0.01 \mathrm{~mol} \mathrm{~L}^{-1}$ & $\mathrm{~g} \mathrm{dm}^{-3}$ & $m g \mathrm{dm}^{-1}$ & $--1-1-1$ & $--m$ & $\mathrm{dm}^{-}$ & 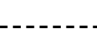 & ---- & $\%$ \\
\hline Eutrudox & 5.5 & 32 & 23 & 4.8 & 32 & 14 & 28 & 78.8 & 64 \\
\hline \multirow[t]{2}{*}{ Paleudalf } & 4.3 & 10 & 32 & 1.7 & 6 & 1 & 28 & 36.7 & 23 \\
\hline & \multicolumn{9}{|c|}{ Eight days after liming and chemical fertilization } \\
\hline Eutrudox & 5.5 & 32 & 67 & 9.6 & 49 & 26 & 25 & 109.6 & 77 \\
\hline Paleudalf & 5.6 & 10 & 79 & 7.8 & 32 & 14 & 13 & 66.8 & 81 \\
\hline
\end{tabular}


1. Soils were wetted to $70 \%$ of the pot water holding capacity. The experimental treatments were further divided into two sub-treatments, one with ${ }^{15} \mathrm{~N}$ labeled above-ground parts and non-labeled roots, and another with non-labeled above-ground parts and ${ }^{15} \mathrm{~N}$ labeled roots.

\section{Corn hybrid sowing}

Ten seeds per pot of AG-303 corn hybrid were sown and soon after the emergence the plants were thinned to four plants per pot. Thirty days after sowing pots were fertilized with $238 \mathrm{mg} \mathrm{P}\left(\mathrm{KH}_{2} \mathrm{PO}_{4}\right), 500$ $\mathrm{mg} \mathrm{K}\left(\mathrm{K}_{2} \mathrm{SO}_{4}\right)$, and $125 \mathrm{mg} \mathrm{Mg}$ (magnesium sulphate). The fertilization was repeated after 30 days, except for $\mathrm{Mg}$. Corn plants were sampled five times, at 20, 30, 40, 60 and 100 days after emergence (DAE). Plants were separated in above ground part and roots and the dry mass (DM) was determined at each sampling. The sampled materials were washed and oven dried at $60^{\circ} \mathrm{C}$ and ground in a rotary mill with stainless steel blades.

\section{Nitrogen concentration and isotopic composition in plant tissues and soil}

Nitrogen concentration in plant tissues was determined using the semi-micro Kjeldahl method, including the $\mathrm{NO}_{3}^{-}-\mathrm{N}$, according to Bremner (1996). Samples for isotopic analysis were processed by the modified Dumas combustion method, according to Proksch (1969), and the isotopic composition was determined using a VARIAN MAT model CH4 mass spectrometer (Trivelin et al., 1973).

The percentage and amount of nitrogen in the plant derived from the labeled green manure part (Npdfgm; \% and QNpdfgm; mg per pot) in the soil
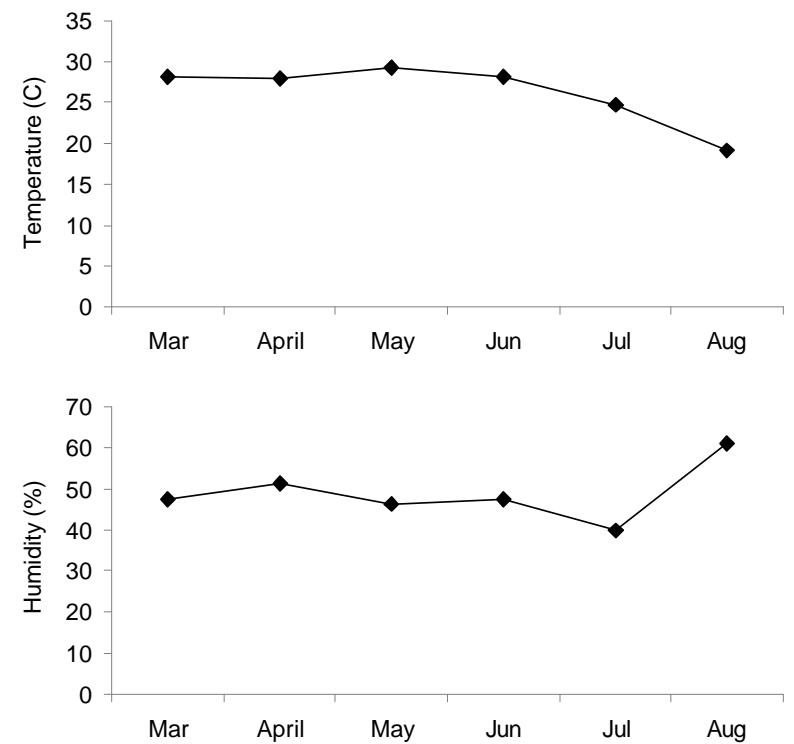

Figure 1- Temperature and relative humidity changes inside the greenhouse during the experimental period.
(Nsdfgm; \% and QNsdfgm; mg per pot), and in the soil mineral $\mathrm{N}$ (Nsmdfgm; \% and QNsmdfgm; $\mathrm{mg} \mathrm{kg}^{-1}$ ) were calculated based on the isotopic results (atom \%), using the following equations (Trivelin et al., 1994):

$\operatorname{Npdfgm}(\%)=(\mathrm{a} / \mathrm{b}) \cdot 100$

QNpdfgm $(m g$ per pot $)=[$ Npdfgm $(\%) / 100] . N A(m g$ per pot)

where $\mathrm{a}$ and $\mathrm{b}$ are ${ }^{15} \mathrm{~N}$ abundance values (atom $\%$ in excess) in the plant (corn) and in the green manure (above ground parts and roots), respectively; NA is the amount of accumulated nitrogen in the plant (mg per pot). Similarly for the soil N, a and $b$ are ${ }^{15} \mathrm{~N}$ abundance values (atom \% in excess) in the soil and in the labeled green manure (above ground parts and roots) respectively; NA is total amount of nitrogen in the soil (mg per pot). For the soil mineral N, the procedures were also similar.

Soil nitrogen was quantified in samples dried at $60^{\circ} \mathrm{C}$, which were subsampled, and dried at $110^{\circ} \mathrm{C}$, to later adjust them for dry weight. The soil total-N analyses were made by digestion-distillation method according to Buresh et al. (1982). The isotopic N analyses were performed in the extract obtained for total-N determination after wet drying (Rittenberg, 1946), modified according to IAEA (1976).

Mineral N (nitrate and ammonium) was determined after extraction with $2 \mathrm{~mol} \mathrm{~L}^{-1} \mathrm{KCl}$, according to Buresh et al. (1982). The distilled extracts were also used for ${ }^{15} \mathrm{~N}$ determinations. Isotopic determinations of soil mineral $\mathrm{N}$ were possible only up to the $3^{\text {rd }}$ sampling (40 DAE) because of the low soil mineral $\mathrm{N}$ content afterwards.

The soil mineral nitrogen content was calculated in mg per pot by multiplying the value in $\mathrm{m} \mathrm{kg}^{-1}$ by the total mass of oven-dried soil contained in the pots. The total mineralized $\mathrm{N}$ was calculated for the sunn hemp and velvet bean sand, without green manure, by adding the soil mineral $\mathrm{N}$ to the treatments of whole plant total $\mathrm{N}$.

The $\mathrm{N}$ balance in the soil-plant system was calculated considering the nitrogen use efficiency by the whole plant, as well as the $\mathrm{N}$ present in the soil and the mineral $\mathrm{N}$. The losses were determined by the difference between the $\mathrm{N}$ input via green manure plus soil $\mathrm{N}$, and that taken up by the plant.

Nitrogen use efficiency (UE) was calculated according to equations 3,4 and 5:

$\%$ plant $\mathrm{UE}=(\mathrm{QNapdfgm}+\mathrm{QNrdfgm} / \mathrm{QNagm}) \times 100$

$\%$ soil $\mathrm{UE}=(\mathrm{QNsdfgm} / \mathrm{QNagm}) \times 100$ 
$\%$ mineral $\mathrm{UE}=(\mathrm{QNmsdfgm} / \mathrm{QNagm}) \times 100$

In the $\mathrm{N}$ balance, the applied nutrient amounts were computed in relation to those derived from the green manure (mg per pot), and soil $\mathrm{N}$ recovered was the sum of $\mathrm{N}$-mineral plus total $\mathrm{N}$ in the soil coming from the green manure.

A completely randomized design with a factorial arrangement of treatments was used. Treatments were the combinations among two legumes (green manures), two soils; two legume parts labelled with ${ }^{15} \mathrm{~N}$ (shoots or roots); five sampling times and three replicates. The experiment had also an additional treatment, without green manuring, consisting of two soils, five sampling times and three replications.

Treatment factor means: soil and plant parts were compared by F-test. The Tukey test was used for comparisons between means of treatment factors (velvet bean, sunn hemp and without green manure) and polynomial regression was used to evaluate the effect of sampling times. The Sanest computer program was used to run the analyses.

\section{RESULTS AND DISCUSSION}

The Eutrudox presented higher fertility and higher buffering capacity than the Paleudalf, as it can well be seen by the small change in $\mathrm{pH}$ and the lower reduction in the $\mathrm{H}+\mathrm{Al}$ value, eight days after liming and chemical fertilization (Table 1). Both soils with green manure had higher $\mathrm{N}$ concentrations than those without it. Regardless of soil type, whenever velvet bean was the incorporated source, the $\mathrm{N}$ contents were higher (Table 2), as shown by the higher $\mathrm{N}$ levels in velvet bean compared with sunn hemp (Table 3 ). Higher $\mathrm{N}$ accumulation in velvet bean can be explained by its larger $\mathrm{N}_{2}$ symbiotic fixation under the conditions of this study. No differences were observed in the temperature and relative humidity during the experimental period that would justify differences in the decomposition process (Figure1).

Table 2 shows the mean data of \% Nsdfgm as a function of the incorporated legume plant part for both soils. For the contribution of the legume nitrogen in the Paleudalf soil, the $\mathrm{N}$ supply from the velvet bean was higher. For velvet bean, the total of $35 \%$ had the contribution of $27.8 \%$ from the above ground partand only $7.2 \%$ from the roots, for the Paleudalf soil, which was higher than for the Eutrudox, with contributions of $11.0 \%$ and $2.8 \%$, respectively. For sunn hemp the values were lower for the two soils. These results are consistent with the higher mineralization rate of the organic matter in soils with less clay, as shown above. The lower $\mathrm{C} / \mathrm{N}$ ratio in the velvet bean above ground part as well as in the roots was lower than in sunn hemp (Table 3), favoring its higher mineralization in both soils (Table 2).

Table 2 - Total $\mathrm{N}$ concentrations in the Eutrudox and Paleudalf soils for the treatments and nitrogen percentage derived from the green manure $(\%$ Nsdfgm $)$.

\begin{tabular}{lrcc}
\hline Soil & Velvet bean & Sunn hemp & Without green manure crop \\
\hline Eutrudox & $1315 \mathrm{~A}$ & $1245 \mathrm{~B}$ & $1135 \mathrm{C}$ \\
Paleudalf & $435 \mathrm{~A}$ & $363 \mathrm{~B}$ & $267 \mathrm{C}$ \\
$\mathrm{CV}=7.7 \%$ & & & \\
\hline & & Nsdfgm $(\%)$ & - \\
Paleudalf & $35.0 \mathrm{aA}$ & $22.0 \mathrm{aB}$ & - \\
Eutrudox & $13.8 \mathrm{bA}$ & $8.6 \mathrm{bB}$ & \\
\hline
\end{tabular}

$\mathrm{CV}=8.7 \%$

Means followed by the same lower case letter, in the column, and capital letter, in the rows are not different (Tukey test, $p>0.05$ ).

Table 3 - Chemical characterization of the leguminous plants.

\begin{tabular}{|c|c|c|c|c|c|c|c|c|c|c|c|c|}
\hline \multirow{2}{*}{ Leguminous part } & \multicolumn{12}{|c|}{ Velvet bean } \\
\hline & $\mathrm{C}$ & $\mathrm{N}$ & $\mathrm{P}$ & $\mathrm{K}$ & $\mathrm{Ca}$ & $\mathrm{Mg}$ & $\mathrm{Fe}$ & $\mathrm{Mn}$ & $\mathrm{Zn}$ & $\mathrm{Cu}$ & B & $\mathrm{C} / \mathrm{N}$ \\
\hline & \multicolumn{12}{|c|}{ - } \\
\hline Aerial part & 405 & 27 & 3.1 & 10.2 & 15.8 & 3.0 & 297 & 1133 & 66 & 9 & 50 & 15 \\
\hline \multirow[t]{2}{*}{ Roots } & 336 & 28 & 3.2 & 9.2 & 6.1 & 5.3 & 6285 & 1042 & 124 & 19 & 37 & 12 \\
\hline & \multicolumn{12}{|c|}{ Sunn hemp } \\
\hline Aerial part & 400 & 16 & 1.8 & 7.1 & 8.0 & 3.5 & 111 & 280 & 31 & 5 & 37 & 25 \\
\hline Roots & 300 & 12 & 1.6 & 4.1 & 4.1 & 2.0 & 6078 & 339 & 45 & 10 & 41 & 25 \\
\hline
\end{tabular}


Differences were found between the means of total $\mathrm{N}$ concentrations of both soils, with Eutrudox having $1.259 \mathrm{mg} \mathrm{kg}^{-1}$ and Paleudalf $389 \mathrm{mg} \mathrm{kg}^{-1}$, regardless of treatment, incorporation or not of the green manures, legume plant part, or sampling time. This was largely due to the textural differences between the two soils, which slows down the organic matter decay (Stevenson, 1994; Bayer et al., 2004). This is corroborated by the higher levels of organic matter $(\mathrm{OM})$ in the Eutrudox, $30 \mathrm{~g} \mathrm{dm}^{-3}$ of $\mathrm{OM}$ versus $10 \mathrm{~g} \mathrm{dm}^{-3}$ in the Paleudalf. More than $90 \%$ of $\mathrm{N}$ of the surface layers of most soils is in the organic form (Stevenson, 1982).

The amounts of $\mathrm{N}$ in the above ground part of the corn plant that was derived from the two green manures, as a function of time can be observed in Table 4. No differences among treatments were observed until $40 \mathrm{DAE}$, however at $60 \mathrm{DAE}$ the velvet bean became the major $\mathrm{N}$ supplier to the corn plant, probably due to its larger $\mathrm{N}$ concentration and lower $\mathrm{C} / \mathrm{N}$ ratio (Table 2). The percentage of plant nitrogen derived from the green manure was practically constant during the experiment (Table 4). This fact is not usually observed when mineral fertilizer or another soluble $\mathrm{N}$ source is applied, where a greater proportion of the fertilizer nitrogen use occurs initially, with a reduction in these values in subsequent stages (Ambrosano, 1989; Calvache Ulloa, 1982; Ng Kee Kwong \& Deville, 1994).

Despite the higher amounts of $\mathrm{N}$ accumulated in the corn plants of the Sunn hemp treatments, at the 60 and 100 DAE (Table 5) the amount of $\mathrm{N}$ from the green manures was higher for the velvet bean, at any correspondent date, indicating the total $\mathrm{N}$ supply potential of this plant (Table 4).

The reduction of the amounts accumulated at the end of the cycle followed the same pattern verified

Table 4 - Nitrogen percentage in the corn above ground part derived from the green manure above ground part and roots in function of the time.

\begin{tabular}{lccc}
\hline Sampling times & Above ground part & Roots & Total \\
\hline DAE + & $40.0 \mathrm{a}$ & $5.0 \mathrm{~b}$ & 45.0 \\
20 & $42.4 \mathrm{a}$ & $4.9 \mathrm{~b}$ & 47.3 \\
30 & $41.5 \mathrm{a}$ & $5.1 \mathrm{~b}$ & 46.6 \\
40 & $41.7 \mathrm{a}$ & $5.7 \mathrm{~b}$ & 47.4 \\
60 & $41.6 \mathrm{a}$ & $4.8 \mathrm{~b}$ & 46.5 \\
100 & $\mathrm{~ns}$ & $\mathrm{~ns}$ & \\
F linear & $\mathrm{ns}$ & $\mathrm{ns}$ & \\
F quadratic & & & \\
CV $=6.3 \%$ & &
\end{tabular}

Means followed by the same lower case letter, in the rows, are not different (Tukey test, $p>0.05$ ). ${ }^{+}$DAE - Days after emergence of corn. ns $=$ non significant.

Table 5 - Accumulated nitrogen in the corn above ground part with and without green manure (QN), and amount of $\mathrm{N}$ accumulated in the above ground part of the corn plant derived from the green manure (QNapdfgm) as a function of time.

\begin{tabular}{lccccc}
\hline $\begin{array}{l}\text { Sampling } \\
\text { times }\end{array}$ & $\begin{array}{c}\text { Velvet bean } \\
\text { QN }\end{array}$ & $\begin{array}{c}\text { Velvet bean } \\
\text { QNapdfgm }\end{array}$ & $\begin{array}{c}\text { Sunn hemp } \\
\text { QN }\end{array}$ & $\begin{array}{c}\text { Sunn hemp } \\
\text { QNapdfgm }\end{array}$ & $\begin{array}{c}\text { Without green manure } \\
\text { QN }\end{array}$ \\
\hline 20 & $-194 \mathrm{a}$ & $94 \mathrm{a}$ & $187 \mathrm{a}$ & $74 \mathrm{a}$ & $205 \mathrm{a}$ \\
30 & $340 \mathrm{a}$ & $166 \mathrm{a}$ & $326 \mathrm{a}$ & $138 \mathrm{a}$ & $340 \mathrm{a}$ \\
40 & $433 \mathrm{a}$ & $212 \mathrm{a}$ & $427 \mathrm{a}$ & $170 \mathrm{a}$ & $322 \mathrm{~b}$ \\
60 & $546 \mathrm{~b}$ & $452 \mathrm{a}$ & $819 \mathrm{a}$ & $212 \mathrm{~b}$ & $428 \mathrm{c}$ \\
100 & $423 \mathrm{~b}$ & $310 \mathrm{a}$ & $573 \mathrm{a}$ & $160 \mathrm{~b}$ & $322 \mathrm{c}$ \\
F linear & $*$ & $*$ & $*$ & $n$ & $*$ \\
F quadratic & $*$ & $*$ & $*$ & 0.10 & $*$ \\
$\mathrm{R}^{2}$ & 0.81 & 0.22 & 0.74 & & 0.64 \\
$\mathrm{CV}$ QN $=18.7 \%$ & & $\mathrm{CV}$ QNapdfgm $=28.7 \%$ & & \\
\hline
\end{tabular}

Means followed by the same lower case letter, in the rows, in each QN or QNapdfgm, are not different (Tukey test, $p>0.05$ ). ${ }^{+} \mathrm{DAE}$ - Days after emergence of corn. *Significant at $(p<0.05)$. 
for the total nitrogen and it is likely due to the loss of nitrogenous compounds from the mature or pre-senescent leaves, which can happen next to the transpiratory strem (Stutte et al., 1979; Silva \& Stutte, 1981).

The occurrence of the nitrogen decline accumulation in the above ground part of the corn plant, at the end of the cycle (Table 5) was also reported by other authors (Flores, 1986; Villas Bôas, 1990), as well as for sugarcane (Ng Kee Kwong \& Deville, 1994). The probable cause of this could be the fact that some $\mathrm{N}$ of the above ground part was redistributed to the root system, as well as lost to the atmosphere by volatilization through the leaves via transpiratory strem in either immature or senescing leaves. According to Farquhar et al. (1979), an $\mathrm{NH}_{3}$ gaseous losses occurs through the leaves due to an increase in proteolysis during senescence.

The accumulation of $\mathrm{N}$ in corn roots increased with time. These results indicate that there are also losses due to shedding, root exudation and root death (Allison, 1966), and that losses of $\mathrm{N}$ from the above ground part are much more expressive, that the above ground part $\mathrm{N}$ can be translocated to the roots reflecting on the accumulation of $\mathrm{N}$ in roots (Figure 2). There was an increase in dry matter mass of the corn above ground part until $100 \mathrm{DAE}$. At this stage, the plants were starting to flower. The only difference observed was at the first date (20 DAE), when the control plants grew more than those with green manure (Table 6). The results suggest that, at this time there was no net immobilization of nitrogen, however, by adding corn as a test plant, the initial productivity was harmed by the treatments with green manure as observed in Table 6. After that initial period, the corn productivity was similar to the control treatment. Regarding corn roots, there was an increase in DM with time, and as observed for the aerial part without treatment effects beyond 20 DAE (Table 6).

Differences occurred between the total soil $\mathrm{N}$ amount and concentration that came from the green manure above ground part over time (Table 4). The above ground part contribution was on average $16.3 \%$, compared with $3.5 \%$ for roots, indicating that the above ground part participation was four times larger than that of the roots, reflecting the greater amount added from the above ground part. Over time the variable described a quadratic curve with the largest contribution at $20 \mathrm{DAE}$, decreasing afterwards until $60 \mathrm{DAE}$ and rising again at $100 \mathrm{DAE}$; the same was not verified in roots. These results are mainly due to the uptake of the $\mathrm{N}$ incorporated by the corn from the green manure (Table 6) in a quadratic form, opposite to what was described in Table 7, with the highest $\mathrm{N}$ uptake at $60 \mathrm{DAE}$ and a decrease thereafter up to 100 DAE. A constant release of nitrogen from the roots was also observed.

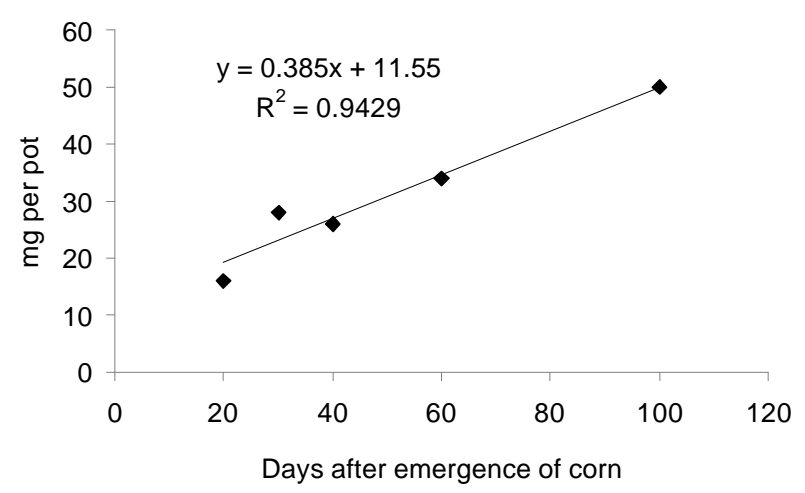

Figure 2 - Amount of $\mathrm{N}$ accumulated in corn roots derived from the green manure (QNrdfgm).

Table 6 - Dry mass production of the corn above ground part and roots with and without green manure treatments, as a function of sampling time.

\begin{tabular}{|c|c|c|c|c|c|c|}
\hline \multirow{2}{*}{ Sampling } & \multicolumn{2}{|r|}{ Sunn hemp } & \multicolumn{2}{|c|}{ Velvet bean } & \multicolumn{2}{|c|}{ Without green manure } \\
\hline & Roots & Above ground part & Roots & Above ground part & Roots & Above ground part \\
\hline & $-\cdots-$ & 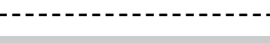 & $\cdots$ & g per pot --- & ---1 & $-\cdots-1$ \\
\hline 20 & $2.0 \mathrm{a}$ & $4.9 \mathrm{a}$ & $1.9 \mathrm{a}$ & $4.5 \mathrm{a}$ & $2.2 \mathrm{~b}$ & $5.3 \mathrm{~b}$ \\
\hline 30 & $3.3 \mathrm{a}$ & $10.7 \mathrm{a}$ & $3.2 \mathrm{a}$ & $8.9 \mathrm{a}$ & $4.1 \mathrm{a}$ & $10.8 \mathrm{a}$ \\
\hline 40 & $6.0 \mathrm{a}$ & $17.6 \mathrm{a}$ & $3.4 \mathrm{a}$ & $13.7 \mathrm{a}$ & $5.3 \mathrm{a}$ & $14.3 \mathrm{a}$ \\
\hline 60 & $11.3 \mathrm{a}$ & $37.5 \mathrm{a}$ & $8.7 \mathrm{a}$ & $41.3 \mathrm{a}$ & $12.2 \mathrm{a}$ & $38.4 \mathrm{a}$ \\
\hline 100 & $19.5 \mathrm{a}$ & $61.8 \mathrm{a}$ & $18.5 \mathrm{a}$ & $62.9 \mathrm{a}$ & $13.8 \mathrm{a}$ & $55.4 \mathrm{a}$ \\
\hline F linear & $*$ & $*$ & $*$ & $*$ & * & $*$ \\
\hline F quadratic & $*$ & $*$ & $*$ & $*$ & $*$ & $*$ \\
\hline $\mathrm{R}^{2}$ & 0.86 & 0.97 & 0.79 & 0.92 & 0.84 & 0.95 \\
\hline
\end{tabular}

Means followed by the same lower case letter, in the rows, in each above ground part or roots, are not different (Tukey test, $p>0.05$ ). ${ }^{+}$DAE - Days after emergence of corn. * Significant $(p<0.05)$; ns non significant. 
The soil mineral N (nitrate and ammonium) contents were higher until $40 \mathrm{DAE}$ in the velvet bean treatment followed by the sunn hemp and the control (Table 8). Beyond $60 \mathrm{DAE}$ the values were lower than $1.6 \mathrm{mg}$ $\mathrm{kg}^{-1}$, without differences among treatments (Table 8). For the sunn hemp there were time differences, with a decline in the green manure contribution to the soil mineral N. However, this did not happen with the velvet bean treatment, indicating that, besides the largest contribution of the green manure plants to the soil mineral $\mathrm{N}$, there also was a greater mineralization, since the testplant continued absorbing the mineral $\mathrm{N}$ from the soil.

The Paleudalf had higher mineral $\mathrm{N}$ content than the Eutrudox, regardless of the soil sampling time (Table 9). Ladd et al. (1983) also found higher organic matter mineralization in low-N soils. The authors observed that $13 \%$ of the mineral nitrogen originated from the added plant residue, compared to $5 \%$ in the high$\mathrm{N}$ soil. Jans-Hammermeister et al. (1993) observed N mineralization rates in two soils after adding pea shoot and verified that the higher rates were associated with soils having lower clay content. Similar results were also verified by Ladd et al. (1981a) and other authors cited by Bartholomew (1965). Ambrosano et al. (2003) worked with these soils in a mineralization study without plant development and verified that after seven days of incubation with Sunn hemp, velvet bean and bean residue, the total mineral $\mathrm{N}$ amounts resulting from the treatments were the same.

Regarding the accumulation of nitrogen in the corn shoot (mg per pot), there was a quadratic response with increments up to $60 \mathrm{DAE}$, decreasing thereafter (Table 5). The corn plant did not present growth differences among treatments up to $30 \mathrm{DAE}$, due to the low plant development and nitrogen uptake, but there was greater $\mathrm{N}$ accumulation in plants under the green manure treatments, after 40 DAE showing that plants started to take up more nitrogen from that

Table 7 - Amount of total soil nitrogen (mean of the two soils) from parts of the green manure labeled with ${ }^{15} \mathrm{~N}$ (QNsdgm, mg per pot) and percentage of total soil $\mathrm{N}$ from parts of the green manure labelled with ${ }^{15} \mathrm{~N}$ at the sampling times.

\begin{tabular}{|c|c|c|c|c|}
\hline \multirow{2}{*}{ Sampling } & \multicolumn{2}{|c|}{ QNsdgm } & \multicolumn{2}{|c|}{ Nsdgm } \\
\hline & Aerial part & Roots & Aerial part & Roots \\
\hline $\mathrm{DAE}^{+}$ & - & $t$----. & 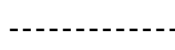 & - \\
\hline 20 & $622 \mathrm{a}$ & $121 \mathrm{~b}$ & $17.9 \mathrm{a}$ & $3.8 \mathrm{~b}$ \\
\hline 30 & $576 \mathrm{a}$ & $122 \mathrm{~b}$ & $17.2 \mathrm{a}$ & $3.5 \mathrm{~b}$ \\
\hline 40 & $529 \mathrm{a}$ & $106 \mathrm{~b}$ & $15.9 \mathrm{a}$ & $3.2 \mathrm{~b}$ \\
\hline 60 & $491 \mathrm{a}$ & $116 \mathrm{~b}$ & $14.9 \mathrm{a}$ & $3.6 \mathrm{~b}$ \\
\hline 100 & $524 \mathrm{a}$ & $107 \mathrm{~b}$ & $15.8 \mathrm{a}$ & $3.4 \mathrm{~b}$ \\
\hline F. linear & $*$ & ns & $*$ & ns \\
\hline F. quadratic & * & ns & * & ns \\
\hline $\mathrm{R}_{2}$ & 0.96 & - & 0.95 & - \\
\hline
\end{tabular}

${ }^{+}$DAE - Days after emergence of corn. Means followed by same lower case letters in rows, for each factor, are not different (Tukey test, $p>0.05)$. C.V. (\%) $18.0(\mathrm{QNsdgm})$ and 8.7 (Nsdgm). *Significant at $(p<0.05)$ and $\mathrm{ns}=$ non significant.

Table $8-\mathrm{N}^{-\mathrm{NH}_{4}+}+\mathrm{N}_{-} \mathrm{NO}_{2}^{-}+\mathrm{N}_{-} \mathrm{NO}_{3}^{-}$concentrations over time.

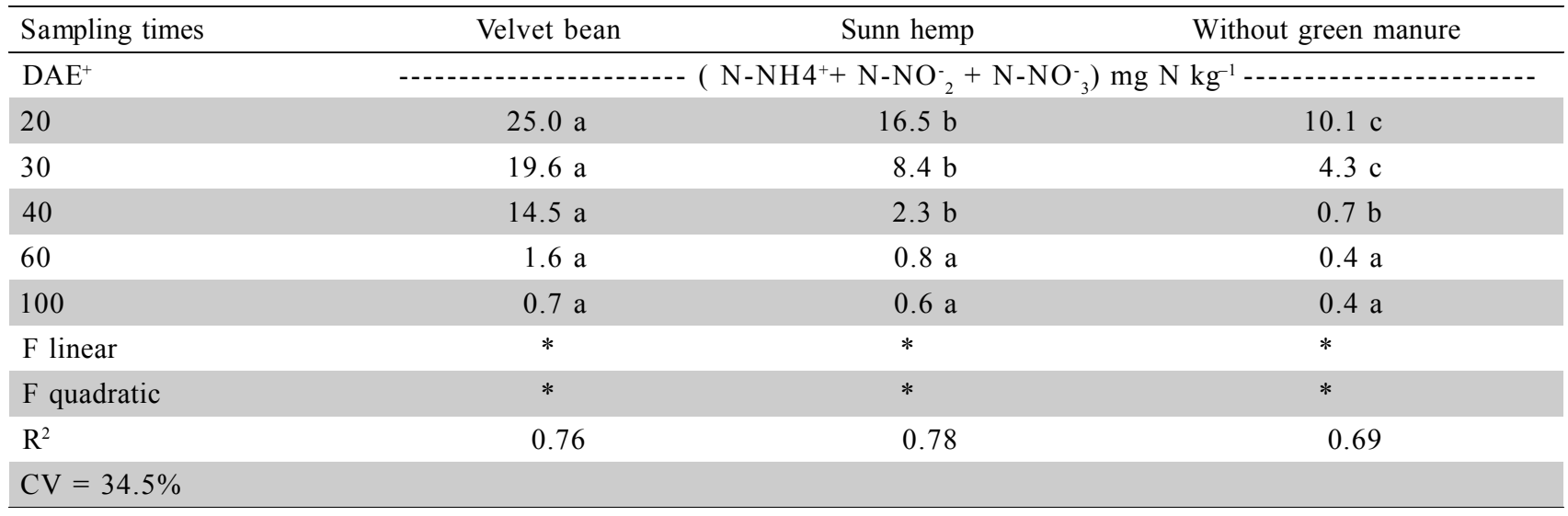

Means followed by the same lower case letter, in the rows, are not different (Tukey test, $p>0.05$ ). ${ }^{+}$DAE - Days after emergence of corn. * Significant at $(p<0.05)$. 
Table 9 - Soil mineral $\left(\mathrm{N}^{-\mathrm{NH}_{4}}{ }^{+}+\mathrm{N}_{-} \mathrm{NO}_{2}^{-}+\mathrm{N}-\mathrm{NO}_{3}\right)$ levels in the Eutrudox and Paleudalf.

\begin{tabular}{lcc}
\hline Treatment & Eutrudox & Paleudalf \\
\hline & $-\cdots-\cdots \mathrm{mg} \mathrm{N} \mathrm{k}^{-1}-\cdots-\cdots-$ \\
Velvet bean & $10.0 \mathrm{~b}$ & $14.6 \mathrm{a}$ \\
Sunn hemp & $4.5 \mathrm{~b}$ & $6.9 \mathrm{a}$ \\
Without green manure & $3.3 \mathrm{a}$ & $3.3 \mathrm{a}$
\end{tabular}

$\mathrm{CV}=34.5 \%$

Means followed by the same lower case letter, in the rows, are not different (Tukey test, $p>0.05$ ).

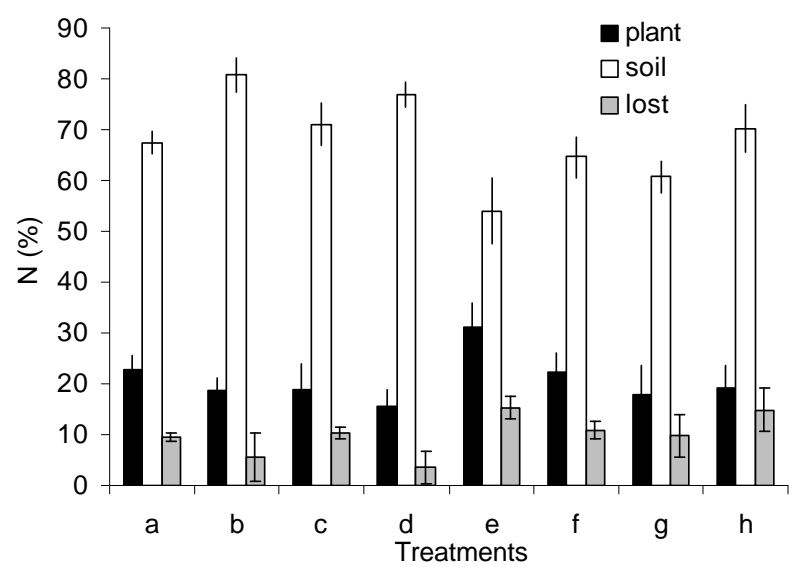

Figure 3- Nitrogen balance in the soil-green manuring-crop system. a- sunn hemp Eutrudox plant shoot; b- sunn hemp Eutrudox roots; c- velvet bean Eutrudox plant shoot; d- velvet bean Eutrudox roots; e- sunn hemp Paleudalf plant shoot; f- sunn hemp Paleudalf roots; g- velvet bean Paleudalf plant shoot; h- velvet bean Paleudalf roots.

stage onwards and these treatments revealed conditions of supplying it. The Sunn hemp treatment plants accumulated more nitrogen than those under the velvet bean treatment after 60 DAE. $80 \%$ of the $\mathrm{N}$ added by the legume roots remained in the Eutrudox and less than $20 \%$ was taken up by the corn plant, indicating that this added material, with high $\mathrm{C} / \mathrm{N}$ ratio, stays longer in the soil (Figure 3).

Larger $\mathrm{N}$ amounts of the green manure were absorbed by corn plants (more than 20\%) for the Paleudalf, and a larger amount of $\mathrm{N}$ was lost from the system, indicating a higher mineralization of nitrogen in this soil. In studies involving the addition of organic $\mathrm{N}$ to soils (Azam et al., 1985; Ambrosano, 1995; Muraoka et al., 2002; Silva, 2005), the N utilization rarely exceeded $20 \%$ and indicates that the greatest proportion of $\mathrm{N}$ contained in the dry matter goes to the soil (Ladd et al., 1981b; Harris \& Hesterman, 1990). Thus, the green manures have beneficial effect to the subsequent crop as well as to other crops in a rotation system, due to their residual effect

\section{REFERENCES}

ALLISON, F.E. The fate of nitrogen applied to soils Advances in Agronomy, v.18, p.219-258, 1966.

AMBROSANO, E.J. Avaliação do crescimento e aproveitamento de fertilizante nitrogenado pelo capim colonião var. Tobiatã em diferentes épocas. Piracicaba: USP/ESALQ, 1989. 110p. Dissertação (Mestrado).

AMBRosANO, E.J. Dinâmica do nitrogênio dos adubos verdes, crotalária júncea (Crotalaria juncea) e mucuna-preta (Mucuna aterrima) em dois solos cultivados com milho. Piracicaba: USP/ ESALQ, 1995. 83p. Tese (Doutorado).

AMBROSANO, E.J.; TRIVELIN, P.C.O.; MURAOKA, T. Técnica para marcação dos adubos verdes crotalária júncea e mucunapreta, com ${ }^{15} \mathrm{~N}$ para estudos de dinâmica do nitrogênio. Bragantia, v.56, p.219-224, 1997.

AMBROSANO, E.J.; TRIVELIN, P.C.O.; CANTARELLA, H.; AMBROSANO, G.M.B.; MURAOKA, T. Nitrogen mineralization in soils amended with sunnhemp, velvet bean and common bean residues. Scientia Agricola, v.60, p.133$137,2003$.

AMBROSANO, E.J.; TRIVELIN, P.C.O.; CANTARELLA, H.; AMBROSANO, G.M.B.; SCHAMMAS, E.A.; GUIRADO, N.; ROSSI, F.; MENDES, P.C.D.; MURAOKA, T. Utilization of nitrogen from green manure and mineral fertilizer by sugarcane. Scientia Agricola, v.62, p.534-542, 2005.

AZAM, F.; MALIK, K.A.; SAJJAD, M.I. Transformations in soil and availability to plants of ${ }^{15} \mathrm{~N}$ applied as inorganic fertilizer and legume residues. Plant and Soil, v.86, p.3-13, 1985.

AZAM, F.; MALIK, K.A.; SAJJAD, M.I. Uptake by wheat plants and turnover within soil fractions of residual $\mathrm{N}$ from leguminous plant material and inorganic fertilizer. Plant and Soil, v.95, p.97-108, 1986.

BARTHOLOMEW, W.V. Mineralization and immobilization of nitrogem in the decomposition of plant and animal residues. In: BARTHOLOMEW, W.V.; CLARK, F.E. (Ed.) Soil nitrogen. Madison: American Society of Agronomy, 1965. p.287-306. (Agronomy Monograph, 10).

BAYER, C.; MIELNICZUK, J.; MARTIN-NETO, L.; ERRNANI, P.R. Stocks and humification degree of organic matter fractions as affected by no-tillage on subtropical soil. Plant and Soil, v.238, p.133-140, 2002.

BREMNER., J.M. Nitrogen-total. In: SPARKS, D.L. (Ed.) Methods of soil analysis. Madison: Soil Science Society of America, 1996. p.1085-1121.

BURESH, R.J.; AUSTIN, E.R.; CRASWELL, E.T. Analytical methods in ${ }^{15} \mathrm{~N}$ research. Fertilizer Research, v.3, p.337-62, 1982.

CALVACHE ULLOA, A.M.; LIBARDI, P.L.; REICHARDT, K. Utilização do nitrogênio fertilizante por dois híbridos de milho. Campinas: Fundação Cargill, 1982. 66p.

FARQUHAR, G.D.; WETSELAAR, R.; FIRTH, P.M. Ammonia volatilization from senescing leaves of maize. Science, v.203, p.257-1258, 1979.

FLORES, L.M. Avaliação quantitativa da eficiência de utilização de duas fontes de nitrogênio, $\mathrm{CO}(15 \mathrm{NH} 2) 2$ e (15NH4)2SO4 pela cultura de milho (Zea mays L.). Piracicaba: USP/ESALQ, 1986. 103p. Dissertação (Mestrado).

GALLO, P.B.; SAWAZAKI, E.; HIROCE, R.; MASCARENHAS, H.A.A. Produção de milho afetada pelo nitrogênio mineral e cultivos anteriores com soja. Revista Brasileira de Ciência do Solo, v.7, p.149-152, 1983.

GALlO, P.B.; MASCARENHAS, H.A.A.; BATAGLIA, O.C.; QUAGGIO, J.A. Interação calagem-adubação nitrogenada na produção de sorgo sob deficiência hídrica em rotação com soja. Bragantia, v.45, p.231-238, 1986.

HARRIS, G.H.; HESTERMAN, O.B. Quantifying the nitrogen contribution from alfafa to soil and two succeeding crops using nitrogen-15. Agronomy Journal, v.82, p.129-134, 1990. 
INTERNATIONAL ATOMIC ENERGY AGENCY - IAEA. Tracer manual on crops and soils. Viena: IAEA, 1976. p.277. (Technical Reports Series, 171).

JANS-HAMMERMEISTER, D.C.; McGILL, W.B.; JENSEN, T.L. Nitrogen accumulations and relative rates of mineralization in two soils following legume green manuring. Canadian Journal of Soil Science, v.74, p.23-28, 1993.

NG KEE KWONG, K.F.; DEVILLE, J. Application of ${ }^{15} \mathrm{~N}$ - labelled urea to sugar cane through a drip-irrigation system in Mauritius. Fertilizer Research, v.39, p.223-228, 1994.

KANTHACK, R.A.D.; MASCARENHAS, H.A.A.; CASTRO, O.M.; TANAKA, R.T. Nitrogênio aplicado em cobertura no milho após tremoço. Pesquisa Agropecuária Brasileira, v.26, p.99-104, 1991.

LADD, J.N.; OADES, J.M.; AMATO, M. Microbial biomass formed from ${ }^{14} \mathrm{C}$, ${ }^{15} \mathrm{~N}$-labelled plant material decomposing in soils in the field. Soil Biology \& Biochemistry, v.13, p.119-126, 1981a.

LADD, J.N.; OADES, J.M.; AMATO, M. Distribution and recovery of nitrogen from legume residues decomposing in soils sown to wheat in the field. Soil Biology \& Biochemistry, v.13, p.251$256,1981 b$.

LADD, J.N.; AMATO, M.; JACKSON, R.B.; BUTLER, J.H.A. Utilization by wheat crops of nitrogen from legume residues decomposing in soils in the field. Soil Biology \& Biochemistry, v.15, p.231-238, 1983.

MASCARENHAS, H.A.A; TANAKA, R.T.; COSTA, A.A.; ROSA, F.V.; COSTA, V.F. Efeito residual das leguminosas sobre o rendimento físico e econômico da cana-planta. Campinas: Instituto Agronômico de Campinas, 1994. 15p. (Boletim Científico IAC, 32).

MONTOJOS, J.C.; GARGANTINI, H. Fixação do nitrogênio do ar pelas bactérias que vivem em simbiose com as raízes das leguminosas. Bragantia, v.22, p.731-739, 1963.

MULLER, M.M.; SUNDMAN, V. The fate of nitrogen $\left({ }^{15} \mathrm{~N}\right)$ released from different plant materials during decomposition under field conditions. Plant and Soil, v.105, p.133-139, 1988.

PEREIRA, J.C.V.N.A.; MASCARENHAS, H.A.A; MARTINS, A.L.M.; BRAGA, N.R.; SAWAZAKI, E.; GALLO, P.B. Efeito da adubação nitrogenada em cobertura no cultivo contínuo do milho e do algodão e em rotação com soja. Revista de Agricultura, v.63, p.95-108, 1988.

PROKSCH, G. Routine analysis of ${ }^{15} \mathrm{~N}$ in plant material by massspectrometry. Plant and Soil, v.31, p.380-384, 1969.

RITTENBERG, D. The preparation of gas sample for massspectrometric analysis. In WILSON, D.W. (Ed) Preparation and measure of isotopic tracers. Ann Arbor: Edwads, 1946. p. 31
SILVA, P.R.F.; STUTTE, C.A. Nitrogen loss in conjunction with transpiration from rice leaves as influenced by growth stage, leaf position and N supply. Agronomy Journal, v.73, p.3848, 1981.

SILVA, R. Potencial da mucuna preta como adubo verde para o arroz-de-sequeiro em latossolo amarelo da amazônia. Piracicaba: USP/ESALQ, 1991. 136p. Tese (Doutorado).

SILVA, E.C. Manejo da adubação nitrogenada e utilização do nitrogênio $\left({ }^{15} \mathrm{~N}\right)$ da uréia, do milheto e da crotalária pelo milho sob semeadura direta em solo de cerrado. Piracicaba: USP/CENA, 2005. 136p. Tese (Doutorado).

SCIVITTARO, W.B; MURAOKA, T.; BOARETTO, A.E.; TRIVELIN, P.C.O. Transformações do nitrogênio proveniente de mucuna-preta e uréia utilizados como adubo na cultura do milho. Pesquisa Agropecuária Brasileira, v.38, p.14271433, 2003

STEVENSON, F.J. Organic forms of soil nitrogen. In: STEVENSON, F.J. (Ed.) Nitrogen in agricultural soils. Madison: American Society of Agronomy, 1982. p.67-122. (Agronomy Monograph, 22).

STEVENSON, F.J. Humus chemistry: genesis, composition, reactions. 2 ed. New York: John Wiley, 1994. p.59-95.

STUTTE, C.A.; WEILAND, R.T.; BLEM, A.R. Gaseous nitrogen loss from soybean foliage. Agronomy Journal, v.71, p.95-97, 1979.

TA, T.C.; FARIS, M.A. Availability of $\mathrm{N}$ from ${ }^{15} \mathrm{~N}$ labelled alfafa residues to three succeeding barley crops under field conditions. Soil Biology \& Biochemistry, v.22, p.835- 838, 1990.

TANAKA, R.T.; MASCARENHAS, H.A.A.; DIAS, O.S.; CAMPIDELLI, C.; BULISANI, E.A. Cultivo da soja após incorporação de adubo verde e orgânico. Pesquisa Agropecuária Brasileira, v.27, p.1477-1483, 1992.

TRIVELIN, P.C.O.; SALATI, E.; MATSUI, E. Preparo de amostras para análise de ${ }^{15} \mathrm{~N}$ por espectrometria de massas. Piracicaba: USP/CENA, 1973. 41p. (Boletim Técnico, 2).

TRIVELIN, P.C.O.; LARA CABEZAS, W.A.R.; VICTOTIA, R.L.; REICHARDT, K. Evaluation of a ${ }^{15} \mathrm{~N}$ plot design for estimating plant recovery of fertilizer nitrogen applied to sugar cane. Scientia Agricola, v.51, p.226-234, 1994.

VILLAS BÔAS, R.L. Alternativas para aumento da recuperação do nitrogênio da uréia pelo milho (Zea mays L). Piracicaba: USP/ CENA, 1990. 78p. Dissertação (Mestrado).

Received November 30, 2007

Accepted September 12, 2008 